Бурова Е. С. Интеграционные процессы и развитие аграрного сектора стран субрегиона Большого Меконга

\author{
УДК 338.436(59) \\ DOI dx.doi.org/10.24866/1813-3274/2020-2/39-51
}

Е. С. Бурова ${ }^{1}$, Институт Дальнего Востока РАН, г. Москва, Россия

E-mail: epylcina@yandex.ru

\title{
ИНТЕГРАЦИОННЫЕ ПРОЦЕССЫ И РАЗВИТИЕ АГРАРНОГО СЕКТОРА СТРАН СУБРЕГИОНА БОЛЬШОГО МЕКОНГА
}

Аннотация. В статье рассматриваются позитивные эффекты интеграционных процессов в странах субрегиона Большого Меконга (СБМ), который как экономгеографическая дефиниция мало изучен в российской науке. На протяжении длительного периода, начиная с 1990-х гг., страны СБМ демонстрируют положительную динамику и весьма высокие темпы роста. Проведённый анализ показывает постепенный процесс выравнивания и сближения уровней экономического развития стран СБМ, сокращение разрыва между ними, возрастающую роль внешней торговли в целом и взаимной торговли субрегиона в частности. Стратегической отраслью экономики по-прежнему остаётся аграрный сектор, несмотря на повсеместное снижение его доли в производстве ВВП и обеспечении занятости населения. Его развитие рассматривается как ключевой фактор поддержания продовольственной безопасности, а также снижения уровня бедности населения. Для аграрного сектора стран СБМ характерны отстающие темпы роста по сравнению с другими отраслями народного хозяйства. Однако в последние десятилетия аграрный сектор стран СБМ демонстрирует позитивные сдвиги. В первую очередь, в сельскохозяйственном производстве субрегиона происходит интенсивный рост продуктивности земли урожайности, хотя и сохраняется её сильная зависимость от погодных условий. Одновременно повсеместно повышается производительность труда. В результате наблюдается рост сельскохозяйственного производства. Происходят изменения и в его структуре. Традиционно монокультурные хозяйства, специализирующиеся на производстве риса, постепенно диверсифицируются, расширяется производство второстепенных товарных культур. Таким образом, увеличивается товарный выход продукции и, как следствие, сельскохозяйственный экспорт. В странах СБМ идёт процесс формирования отличающегося более высокой продуктивностью рыночного хозяйства фермерского типа. Крестьянские хозяйства всё больше ориентируются

\footnotetext{
1 Елена Сергеевна Бурова, магистр востоковедения, научный сотрудник Центра изучения Вьетнама и АСЕАН Института Дальнего Востока РАН, г. Москва, Россия.

Для цитирования: Бурова Е. С. Интеграционные процессы и развитие аграрного сектора стран субрегиона Большого Меконга // Азиатско-Тихоокеанский регион: экономика, политика, право. 2020. № 2. C. $39-51$.

(C) Бурова Е. С., 2020
} 
на региональный и мировой рынок, начинают производить продукцию, обладающую сравнительными преимуществами, участвуя в региональном разделении труда. Происходит также выстраивание вертикально интегрированных предприятий и производственно-сбытовых цепочек в рамках СБМ. Позитивным эффектом интеграционных процессов становится сближение уровня цен на региональном сельскохозяйственном рынке.

Ключевые слова: субрегион Большого Меконга (СБМ), Камбоджа, Лаос, Мьянма, Таиланд, Вьетнам, Гуанси-Чжуанский автономный округ (КНР), провинция Юньнань (КНР), внутрирегиональная торговля, аграрный сектор, интеграционные процессы, производительность труда в аграрном секторе, товарность аграрного сектора, динамика сельскохозяйственного производства, процесс сближения уровней развития, интенсивность торговли, сельскохозяйственный экспорт, производственно-сбытовые цепочки, диверсификация сельскохозяйственного производства, уровень бедности.

Elena S. Burova ${ }^{1}$, Institute of Far Eastern Studies of the Russian Academy of Sciences, Moscow, Russia

E-mail: epylcina@yandex.ru

\section{INTEGRATION PROCESSES AND AGRICULTURAL DEVELOPMENT OF THE GREATER MEKONG SUBREGION COUNTRIES}

Abstract. This article focuses on the positive effects of integration processes in the countries of the Greater Mekong subregion (GMS). The GMS is developing rapidly in the context of an emerging global economy. The analysis highlights a gradual process of converging the levels of economic development of the GMS countries and narrowing the gap between them. It also shows the growing role of foreign trade, in general, and specifically, intra-GMS trade. The agriculture remains a strategic sector of the economy, despite the widespread decline in its share in GDP production and employment. Its development is observed as a key factor in maintaining food security, as well as reducing poverty. The GMS's agriculture is characterized by lagging growth rates in comparison with other sectors of the national economy. However, the GMS's agriculture has shown positive changes. First of all, countries in the region are following a path of intensification, so the yield has increased steadily, although its strong dependence on variable weather con-

\footnotetext{
${ }^{1}$ Elena S. Burova, Master in Oriental Studies, Research Fellow of Center for Vietnamese and ASEAN Studies, Institute of Far Eastern Studies of the Russian Academy of Sciences, Moscow, Russia.

For citing: Burova E. S. Integration processes and agricultural development of the Greater Mekong subregion countries // PACIFIC RIM: Economics, Politics, Law. 2020. No 2. P. 39-51.
} 
ditions is major risk. Much of the agricultural land in the GMS is prone to floods, droughts or both. At the same time, labor productivity has increased too. The structure of agricultural production has changed. Traditionally, monoculture production, specializing in rice crops, is gradually diversifying, and the production of secondary cash crops is expanding makes for the increase in cash output and agricultural export. Agriculture in the GMS has been shifting from traditional subsistence to modern commercial farming. Peasant farms are increasingly oriented to the regional and world markets. They begin to produce products with comparative advantages, participating in the regional division of labor. The construction of vertically integrated enterprises and value chains within the framework of the SBM is also taking place. The positive effect of integration processes is the convergence of prices on the regional agricultural market and direct impact on global consumers.

Key words: the Greater Mekong subregion (GMS), Cambodia, Laos, Myanmar, Thailand, Vietnam, Guangxi, Yunnan, intraregional trade, intra-GMS trade, agriculture, integration processes, labor productivity in agriculture, convergence of development rates, poverty rate, trade intensity, agricultural export, agricultural tradability, value chain, dynamics of agriculture production, agricultural diversification.

\section{Эффекты интеграции в странах СБМ}

Субрегион Большого Меконга (СБМ) как новая экономгеографическая дефиниция мало изучен в российской науке. Он охватывает пять стран Юго-Восточной Азии - Камбоджу, Мьянму, Лаос, Таиланд и Вьетнам, а также приграничные территории Юго-Западного Китая - провинцию Юньнань и Гуанси-Чжуанский автономный район (Г-Ч АР). Входящие в СБМ страны находятся на существенно различных уровнях экономического развития, но уже два десятилетия демонстрируют весьма высокие темпы роста, которые в период 1993-2017 гг. составили 9,3\% [4], что и привлекает внимание исследователей.

Страны СБМ входят в две высоко интегрированные зоны свободной торговли (ЗСТ) - АФТА (для членов АСЕАН) и КАФТА (между Китаем и АСЕАН). Участники благодаря выгодам либерализации торговли смогли активизировать взаимный товарооборот, ускорить процесс своей интеграции в региональную и мировую экономику. Кроме того, в рамках ЗСТ им удалось подключиться к процессу разделения труда в регионе и специализации на производстве товаров, имеющих наибольшие сравнительные преимущества. Тем самым, участие в ЗСТ помогло развитию национальной экономики стран СБМ, помогло увеличить объёмы экспорта и диверсифицировать его.

Позитивные эффекты интеграции подтверждает сближение уровней ВВП на душу населения в интеграционном объединении, которое обычно отражено в сни- 
жении разброса этого показателя по странам-участницам, т.е. его концентрации вокруг среднего уровня ВВП на душу населения (табл. 1). Для корректного сопоставления мы сравнивали ВВП на душу населения по паритету покупательной способности (ППС), так как это позволяет вывести сопоставимые уровни дохода.

Таблицฺа 1

ВВП на душу населения по ППС в 2010-2017 гг.

\begin{tabular}{|l|c|c|c|c|c|c|c|c|c|}
\hline $\begin{array}{l}\text { Страны, } \\
\text { регионы }\end{array}$ & 2010 & 2011 & 2012 & 2013 & 2014 & 2015 & 2016 & 2017 & $\begin{array}{c}\text { Темпы } \\
\text { роста }\end{array}$ \\
\hline СБМ & 6240 & 6674 & 7265 & 7753 & 8151 & 8605 & 9116 & 9737 & $6 \%$ \\
\hline Камбоджа & 2471 & 2658 & 2858 & 3067 & 3291 & 3504 & 3736 & 4001 & $7 \%$ \\
\hline Г-Ч АР & 5607 & 6431 & 7058 & 7715 & 8151 & 8756 & 9454 & 10194 & $9 \%$ \\
\hline Юньнань & 4745 & 5478 & 6278 & 7120 & 7740 & 8259 & 8926 & 9700 & $10 \%$ \\
\hline Лаос & 4133 & 4495 & 4882 & 5293 & 5727 & 6128 & 6549 & 7023 & $7 \%$ \\
\hline Мьянма & 3645 & 3898 & 4225 & 4613 & 5024 & 5384 & 5721 & 6138 & $7 \%$ \\
\hline Таиланд & 13213 & 13535 & 14714 & 15286 & 15651 & 16241 & 16937 & 17870 & $4 \%$ \\
\hline Вьетнам & 4318 & 4632 & 4909 & 5199 & 5546 & 5915 & 6295 & 6775 & $6 \%$ \\
\hline
\end{tabular}

Источник: Greater Mekong Subregion Statistical Database [4]

Как мы видим, подушевой ВВП относительно богатого Таиланда вырос за период 2010-2017 гг. в 1,3 раза, а средние темпы его роста составили 4\%. Страны, уступающие по этому показателю Таиланду (Камбоджа, Лаос, Мьянма и Вьетнам), росли более быстрыми темпами - 6-7\% в год. Ещё более высокую динамику демонстрировали Гуанси-Чжуанский автономный район и провинция Юньнань - 9\% и 10\% в год соответственно.

Также нами обнаружены - на основе формального расчёта - очевидные признаки увеличения сходимости подушевого ВВП по паритету покупательной способности - ППС (рис. 1). Коэффициент вариации подушевого ВВП по ППС в рамках стран СБМ сократился с 60\% до 47\% в 2010- 2017 гг. Таким образом, страны СБМ демонстрируют определённую устойчивость в части его сближения.

В период 2010-2017 гг. у ряда стран СБМ наблюдалась положительная интеграционная динамика. Так, показатель значимости взаимных торговых потоков (т.е. доли стран СБМ в общем товарообороте) увеличился в Таиланде с 16,8\% до 21,1\%, во Вьетнаме - с 18,6\% до 27,1\% [6]. Это вкупе с высоким показателем внешнеторговой открытости экономики этих стран говорит о росте влияния взаимной торговли на их экономику, об улучшении интеграционных связей.

В то же время в Мьянме, Камбодже и Лаосе показатель значимости взаимных потоков сократился, хотя и остаётся весьма внушительным [7]. Так, в Мьянме его 
Бурова Е. С. Интеграционные процессы и развитие аграрного сектора стран субрегиона Большого Меконга

значения уменьшились с 60,3\% до 48,1\%, Камбодже с $36,8 \%$ до 20,7\%, а Лаосе с $83,7 \%$ до 67,6\% [5]. Что касается показателя открытости экономики в 2010-2016 гг., то он, наоборот, повысился в Мьянме, Лаосе и Камбодже - с 32\% до 53\%, с 31,8\% до $53,0 \%$ и с $99 \%$ до $141 \%$ соответственно [4]. Таким образом, можно констатировать, что и для Мьянмы влияние торговых связей со странами СБМ стало более значимым. Повышение доли взаимной торговли свидетельствует о росте интеграции в данном аспекте. Однако при небольших значениях показателя открытости в Мьянме её влияние на экономику страны, очевидно, было невелико.

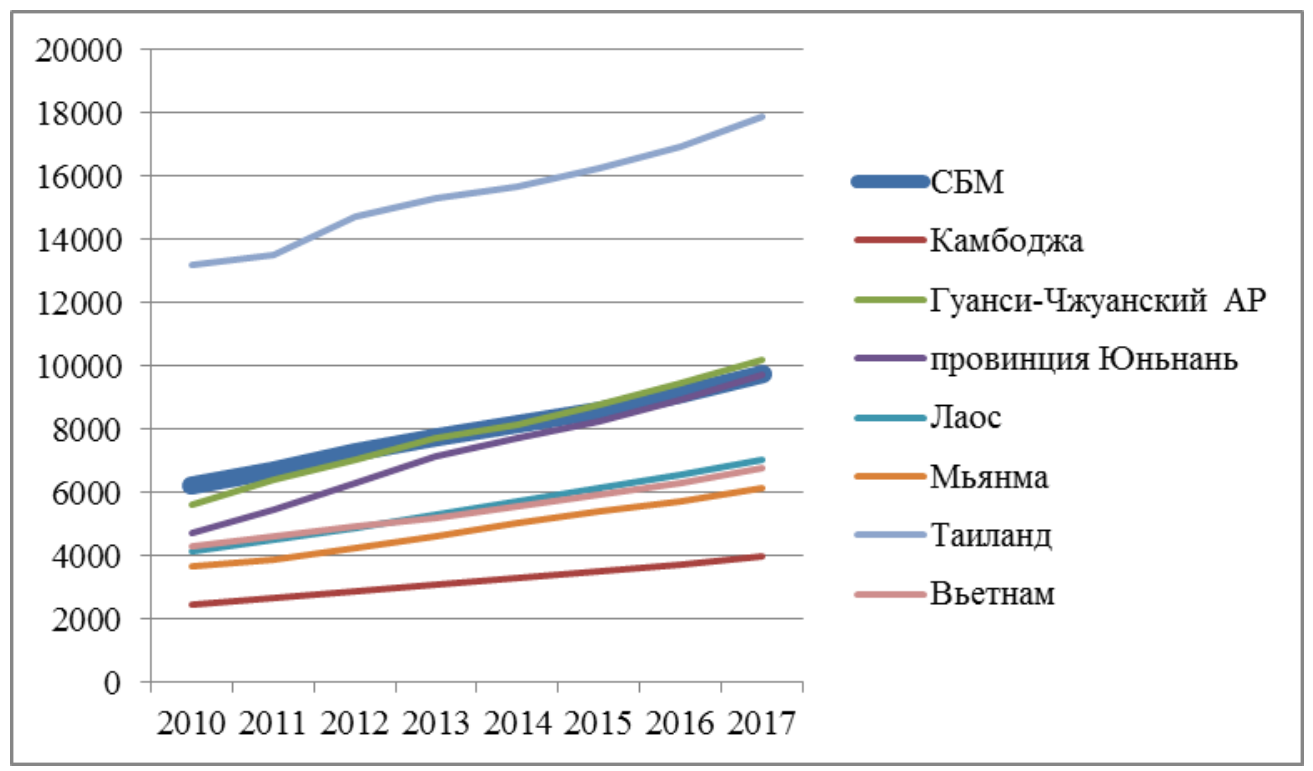

Рис 1. Сближение уровней подушевого ВВП по ППС в странах СБМ Источник: Greater Mekong Subregion Statistical Database [4]

Что касается Камбоджи, то снижение показателя значимости взаимных потоков на фоне увеличения показателя открытости до высоких значений говорит о том, что влияние торговых связей со странами СБМ остаётся всё же весьма большим, хотя и наблюдается диверсификация географии внешней торговли.

Устранение таких элементов протекционизма, как таможенные тарифы, количественные ограничения, стимулирование экспорта, привело к большей стабильности на внутрирегиональном рынке, способствовало росту объёмов торговых операций между странами интеграционного сообщества. Так, в 2010-2017 гг. возрос товарооборот внутри исследуемого субрегиона, его удельный вес в общем объёме торговли этих стран увеличился с 5,7\% до 9,5\% [4]. В абсолютных показателях был отмечен существенный рост в 3,5 раза - со 151 до 483 млрд долл. [4]. Примечательно, что большая часть торговли проходит вдоль так называемых экономических коридоров. 
Для оценки степени торговой интеграции помимо показателей взаимных потоков, открытости и доли внутрирегиональной торговли также используем индекс интенсивности региональной торговли.

Наиболее интенсивно внешнюю торговлю с партнёрами по СБМ ведут Таиланд и Вьетнам. Индекс интенсивности у них превышает пороговое значение в «1» и составляет 2,7 и 2,8 соответственно, указывая на наличие региональных предпочтений ${ }^{1}$. В то же время индекс интенсивности для Камбоджи, Лаоса и Мьянмы находится в пределах $0,1-0,3$, то есть интенсивность региональной торговли у них крайне низка.

Медленная интенсификация региональной торговли стран СБМ во многом обусловлена разным уровнем их экономического развития. Слабая внутренняя торговля между этими странами связана также со схожестью структуры их экспорта на мировые товарные рынки, является сдерживающим фактором развития. Страны СБМ выпускают на внешний рынок однотипные товары, которые обладают небольшими различиями по качеству и ценам. Поэтому экономики стран СБМ не столько дополняют друг друга, сколько конкурируют между собой, а масштабы производства и экспорта Камбоджи и Лаоса мало сопоставимы с Таиландом и Вьетнамом.

\section{Роль аграрного сектора в экономике стран СБМ}

Аграрный сектор традиционно занимал важные позиции в экономике стран СБМ. И хотя его вклад повсеместно сократился и заметно варьируется, будучи более весомым в Мьянме $(26,2 \%)$ и Камбодже $(23,4 \%)$ и менее - в Таиланде $(8,7 \%)$, сельское хозяйство по-прежнему во всех без исключения странах субрегиона оказывает существенное влияние на развитие экономики. Немаловажную роль он сохраняет и в обеспечении занятости населения, достигая $44 \%$ по субрегиону в целом в 2017 г. (табл. 2) [4].

Несмотря на всё это, уровень развития сельскохозяйственного производства в странах СБМ остается достаточно низким. Его отличает исключительно высокая степень зависимости от погодных условий, достаточно слабая диверсификация, низкий уровень жизни основной массы сельских жителей. Для стран СБМ характерен отстающий рост аграрного сектора от других секторов экономики, подверженный существенным колебаниям. В период 2010-2017 гг. он составил 5\% в целом по всем странам СБМ.

\footnotetext{
${ }^{1}$ Regional Trade Intensity Index (RTII) рассчитывается по формуле: RTII = (Xijt+ Mijt)/ (Xjt+ Mjt)/ (Xjt+ $\mathrm{Mjt}) /((\mathrm{Xwt}+\mathrm{Mwt})-(\mathrm{Xjt}+\mathrm{Mjt}))$, где Xijt - экспорт страны і в регион ј в год t, Mijt - импорт страны i из региона $\mathrm{j}$ в год $\mathrm{t}, \mathrm{Xjt}$ - совокупный экспорт региона ј в год $\mathrm{t}, \mathrm{Mjt}$ - совокупный импорт региона ј в год $\mathrm{t}, \mathrm{Xwt}-$ мировой экспорт в год $\mathrm{t}, \mathrm{Mwt}-$ мировой импорт в год $\mathrm{t}$.
} 
Бурова Е. С. Интеграционные процессы и развитие аграрного сектора стран субрегиона Большого Меконга

Таблииа 2

Вклад аграрного сектора в экономику стран СБМ

\begin{tabular}{|l|c|c|c|c|}
\hline \multirow{2}{*}{ Страны, регионы } & \multicolumn{2}{|c|}{ Доля аграрного сектора } & \multicolumn{2}{c|}{ Доля занятых в аграрном секторе (\%) } \\
& 2010 г. & 2017 г. & 2010 г. & 2017 г. \\
\cline { 2 - 5 } & 15,2 & 12,8 & 51,3 & 44,0 \\
\hline СБМ & 33,8 & 23,4 & 54,1 & 26,7 \\
\hline Камбоджа & 17,5 & 14,1 & 54,1 & 49,7 \\
\hline Г-Ч АР & 15,3 & 14,1 & 60,4 & 52,9 \\
\hline Юньнань & 22,5 & 16,1 & 71,4 & 61,3 \\
\hline Лаос & 36,8 & 26,2 & 60,6 & 49,9 \\
\hline Мьянма & 10,5 & 8,7 & 38,2 & 32,7 \\
\hline Таиланд & 18,3 & 15,3 & 48,8 & 40,8 \\
\hline Вьетнам & & & \\
\hline
\end{tabular}

Источник: Greater Mekong Subregion Statistical Database [4]

Руководители стран СБМ подчёркивают приоритетность развития аграрного сектора. В 2007 г. в СБМ была создана межминистерская рабочая группа по сельскому хозяйству, которая отвечает за решение проблем, препятствующих развитию аграрного сектора, укрепление субрегионального сотрудничества в области трансграничной торговли сельскохозяйственной продукцией, привлечение инвестиций и обмен сельскохозяйственной информацией.

Внимательное отношение к аграрному сектору имеет две важнейшие причины. Во-первых, продовольственная безопасность является ключевой задачей многих государства Восточной Азии. Эта цель достижима лишь при самообеспечении аграрной продукцией и создании запасов, гарантирующих обеспечение продовольствием, в том числе в случае неурожаев. Во-вторых, сельское хозяйство является особым сектором экономики, так как оно сильно зависит от условий окружающей среды, на которые человек не всегда может повлиять. Иногда погодные условия вызывают серьёзные отклонения от средних урожаев и, таким образом, серьёзно влияют на доходы крестьян.

Развитие аграрного сектора также рассматривается как ключевой фактор снижения уровня бедности населения. В настоящее время за чертой бедности в странах СБМ проживает 19\% населения, а 15\% его страдает от недоедания [8]. Ведь именно в сельской местности проживает подавляющая часть населения стран СБМ - почти $60 \%$ - и сосредоточена основная масса бедноты [4]. Поскольку большинство бедняков - это первичные производители, развитие аграрного сектора служит обязательным условием для преодоления сельской бедности.

\section{Тенденции развития аграрного сектора стран СБМ}

Во всех странах СБМ основной культурой традиционно остается рис. Его доля в структуре производства зерновых варьируется от 77\% в Лаосе до 92\% в Кам- 
бодже [3]. Следует отметить, что СБМ занимает заметное место в мировом производстве риса: на его долю приходится 44\% мирового производства [8]. Все страны СБМ, за исключением южно-китайских провинций, являются нетто-экспортёрами риса, и их позиции на мировом рынке достаточно весомы. Доля пяти стран СБМ в общемировом экспорте риса составляет 39\% (2017 г.), основной вклад из которых вносят Вьетнам и Таиланд [3].

Несмотря на прочные позиции риса в структуре аграрного сектора стран СБМ, интеграционные процессы, начавшиеся в аграрном секторе, повлекли за собой диверсификацию сельскохозяйственного производства и, как следствие, повышение его товарности. Переход от монокультурности, от традиционного риса, в первую очередь осуществлялся в сторону товарных культур.

Крестьянские хозяйства стали всё больше ориентироваться на спрос на соседних и мировых рынках. Так, например, в Камбодже в середине 2000-х гг. началось производство маниоки, которое увеличилось в 33 раза - с 0,33 млн т до 9,8 млн т. Основная её часть экспортируется в страны-партнёры по СБМ. Главным потребителем камбоджийской маниоки является Таиланд, на него приходится 60\% её экспорта. Второе место занимает Китай, импортируя 38\% камбоджийской маниоки [3].

Как показывают исследования, эффективность производства продукции сельского хозяйства существенно возрастает за счёт новых организационно-экономических форм производства, в том числе вертикально интегрированных предприятий и объединений, способных при содействии государства осуществлять согласованную инновационную политику, долгосрочные вложения, техническое перевооружение и инфраструктурное развитие на своей территории. Инициаторами подобной интеграции и инвестиционного процесса чаще всего выступают перерабатывающие предприятия, нуждающиеся в расширении своей сырьевой базы, ритмичных поставках и высоком качестве сырья.

Так, например, китайские компании создали вертикально интегрированные агропредприятия по производству маниоки в Камбодже, которое демонстрирует устойчивый рост. Производственные издержки в Камбодже существенно ниже, чем в остальных странах региона. В Камбодже они в среднем составляют 396 долл. США/га. В то время как во Вьетнаме и Таиланде - 597 и 578 долл./га соответственно [2]. Следует отметить, что Китай является крупнейшим импортёром сушёной маниоки, которая впоследствии идет на производство биотоплива.

Китай и Таиланд стали также предъявлять спрос на лаосскую маниоку, на их долю приходится 99\% её экспорта [3]. Аналогичная ситуация сложилась и с другими культурами, такими как каучук, табак, маис или фрукты, в частности, бананы [3].

Вместе с тем меняются географические предпочтения и в импортной структуре. Так, например, если в 2011 г. 71\% молочной продукции ввозилось в Камбоджу из Австралии и Новой Зеландии, то к 2017 г. их доля упала до 45\%, вместе с тем 
Бурова Е. С. Интеграционные процессы и развитие аграрного сектора стран субрегиона Большого Меконга

более заметную роль стали играть соседние страны - Таиланд и Вьетнам, поставляя $39 \%$ данной товарной группы [3].

Региональная интеграция вызывает потокообразующие и потокоотклоняющие эффекты. В первом случае речь идёт о налаживании новых торговых связей, создании и развитии новых производств, продукция которых имеет спрос на внутреннем рынке объединения. Во втором случае то, что ранее импортировалось из третьих стран, теперь импортируется из других стран-членов интеграционного объединения.

Изменение рыночной структуры в странах-участницах интеграции и углубление внутриотраслевой конкуренции создают предпосылки для повышения производительности.

В 2010-2016 гг. увеличилась продуктивность сельскохозяйственного производства и наблюдалось сближение её уровней, хотя и динамичность этого процесса весьма неоднородна по СБМ. Так, самыми быстрыми темпами её наращивала Камбоджа $-15 \%$, в результате чего смогла достичь среднего уровня по региону. В то же время Мьянма и Вьетнам демонстрировали более скромные темпы - 4\%, а в Лаосе этот показатель не превысил 1,9\% (табл. 3). В итоге их отставание от средней продуктивности по региону достигло почти двукратных размеров [4].

Таблица 3

\section{Динамика производительности труда в сельском хозяйстве СБМ} (тыс. долл. /работника)

\begin{tabular}{|l|r|r|r|r|r|r|r|}
\hline $\begin{array}{c}\text { Страны, } \\
\text { регионы }\end{array}$ & 2010 & 2011 & 2012 & 2013 & 2014 & 2015 & 2016 \\
\hline СБМ & 703,8 & 740,1 & 782,0 & 825,1 & 871,1 & 907,0 & 1153,4 \\
\hline Камбоджа & 564,1 & 703,1 & 947,7 & 977,5 & 1013,2 & 1055,7 & 1104,9 \\
\hline Г-Ч АР & 891,1 & 971,1 & 1031,8 & 1064,9 & 1102,7 & 1187,2 & 1281,5 \\
\hline Юньнань & 554,2 & 617,2 & 711,1 & 788,3 & 829,2 & 861,1 & $\ldots$ \\
\hline Лаос & 429,6 & 427,5 & 451,5 & 465,9 & 484,4 & 500,8 & 513,4 \\
\hline Мьянма & 490,0 & 494,5 & 513,2 & 542,1 & 569,2 & 608,7 & 605,1 \\
\hline Таиланд & 1261,8 & 1227,8 & 1224,8 & 1329,6 & 1574,1 & 1552,1 & 1468,9 \\
\hline Вьетнам & 520,8 & 532,9 & 543,9 & 561,5 & 576,5 & 617,8 & 652,4 \\
\hline
\end{tabular}

Источник: Greater Mekong Subregion Statistical Database [4]

В СБМ, где зависимость от климатических условий весьма велика, по прогнозам, урожайность зерна только на $20 \%$ зависит от агротехники, а на $80 \%$ - от погодных условий соответствующего года. Из-за нехватки воды в сухой сезон наблюдается низкая продуктивность сельского хозяйства в Камбодже и на северовостоке Таиланда и умеренная в Лаосе, а также в центральных высокогорных райо- 
нах Вьетнама. В наиболее плодородной зоне - дельте Меконга - крестьяне могут получать до трёх урожаев в год. Внедрение современных влагоресурсосберегающих технологий позволяет эффективнее использовать влагу, являющуюся лимитирующим фактором роста растений в сухой сезон.

Страны СБМ вступили в биолого-химический этап интенсификации земледелия, при котором основной эффект проявляется в увеличении продуктивности земли (так, происходит интенсивный рост урожайности благодаря применению новых технологий поливного земледелия, использованию минеральных удобрений и применению высокоурожайных семян).

В 1998-2016 гг. наблюдался заметный рост урожайности и производства зерновых во всех странах СБМ. Прослеживается тенденция сближения её уровней, что говорит о постепенном выравнивании условий сельскохозяйственного производства (табл. 4).

Таблицьа 4

\section{Динамика урожайности и производства зерновых в странах СБМ}

\begin{tabular}{|l|r|r|r|r|r|r|r|r|}
\hline \multirow{2}{*}{$\begin{array}{c}\text { Страны, } \\
\text { регионы }\end{array}$} & \multicolumn{2}{|c|}{1998} & \multicolumn{2}{c|}{2005} & \multicolumn{2}{c|}{2010} & \multicolumn{2}{c|}{2016} \\
\cline { 2 - 9 } & млн т & т/га & \multicolumn{1}{c|}{ млн т } & т/га & млн т & т/га & млн т & т/га \\
\hline СБМ & 107,7 & 3,2 & 138,7899 & 3,7 & 138,7899 & 3,9 & 152,7 & 4,1 \\
\hline Камбоджа & 3,5 & 1,9 & 6,234 & 2,5 & 6,234 & 3,0 & 10,1 & 3,5 \\
\hline Г-Ч АР & 14,5 & 4,8 & 13,829 & 4,6 & 13,829 & 5,0 & 14,1 & 5,5 \\
\hline Юньнань & 11,5 & 3,9 & 12,4668 & 4,1 & 12,4668 & 4,1 & 15,4 & 4,8 \\
\hline Лаос & 1,7 & 2,8 & 2,9406 & 3,5 & 2,9406 & 3,8 & 5,7 & 4,6 \\
\hline Мьянма & 17,5 & 2,9 & 28,7352 & 3,4 & 28,7352 & 3,7 & 28,1 & 3,6 \\
\hline Таиланд & 27,8 & 2,5 & 34,9627 & 3,0 & 34,9627 & 3,1 & 30,4 & 3,0 \\
\hline Вьетнам & 31,0 & 3,9 & 39,6216 & 4,7 & 39,6216 & 5,1 & 48,6 & 5,4 \\
\hline
\end{tabular}

Источник: Greater Mekong Subregion Statistical Database [4]

Урожайность и сбор зерновых культур являются показателями развитости аграрного сектора любой страны. В технологическом аспекте зерновые служат основным элементом в рационе людей и в кормах для отрасли животноводства. По многолетним наблюдениям, в разных странах заметна корреляция урожайности и сбора зерновых с привесом мяса, что свидетельствует о зависимости продуктивности животноводства от показателей растениеводства.

Зерновые культуры в странах СБМ, за вычетом зерна стратегического назначения (питание для человека, корм для животноводства), относятся к группе товаров, вовлечённых во внешнеторговый оборот. Доля зерновых во всех странах субрегиона, кроме Мьянмы, в сельскохозяйственном экспорте была весьма внушительной: 49\% в Камбодже, 18\% в Лаосе и Вьетнаме, 16\% в Таиланде, и лишь 4,4\% в Мьянме [3, 5, 6, 
Бурова Е. С. Интеграционные процессы и развитие аграрного сектора стран субрегиона Большого Меконга

$7,9]$. Зерновое производство - одна из немногих отраслей, которая в наибольшей степени интегрирована в региональный продовольственный рынок [3].

В результате возросших объёмов производства наблюдался и некоторый рост экспорта сельскохозяйственной продукции, хотя и отмеченный колебаниями (рис. 2).

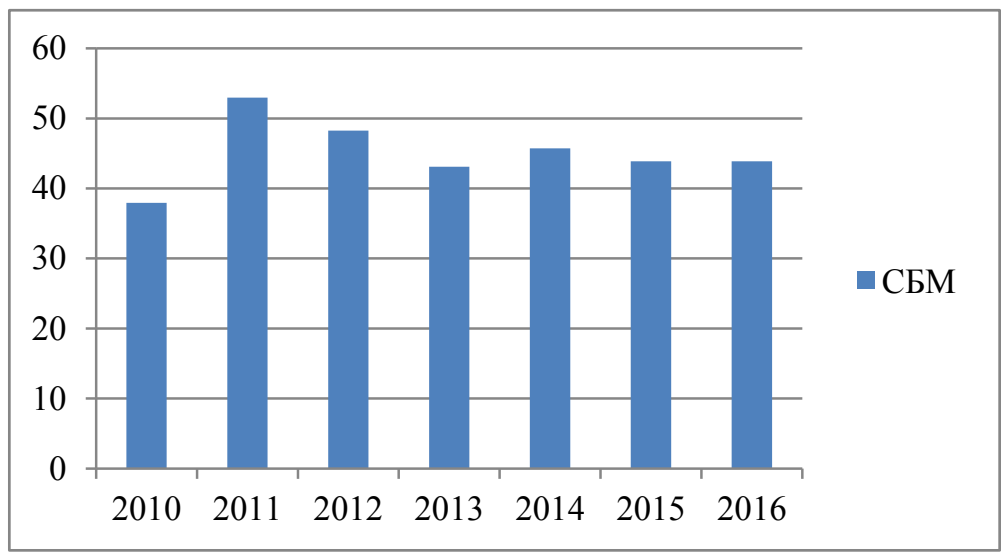

Рис. 2. Динамика экспорта сельскохозяйственной продукции из стран СБМ (млрд долл. США) Источник: FAOSTAT [3]

Следует отметить, что, несмотря на существенное упрощение и облегчение передвижения продукции, всё ещё сохраняются некоторые препятствия. Так, например, в силу того, что не все страны ратифицировали все приложения и протоколы СУТП, эффективность экономических коридоров снижается, как например, в южном коридоре, охватывающем Таиланд, Камбоджу и Вьетнам. Численность камбоджийских грузоперевозчиков, обладающих правами осуществления деятельности на территории Вьетнама, ограничена, а в Таиланде их деятельность и вовсе запрещена. Аналогичным образом деятельность тайских и вьетнамских грузовых автотранспортных компаний ограничена или запрещена в Камбодже. В результате на границе преобладает практика перегрузки грузов, что приводит к задержкам, дополнительным расходам, слабой конкуренции, повышению цен и ограничению вариантов доставки, доступных для широких масс мелких предпринимателей, в том числе фермеров [10].

В период 2010-2017 гг. происходило постепенное выравнивание и в ценовом диапазоне, что свидетельствует о развитии интеграционных процессов в рамках формирования единого сельскохозяйственного рынка. Чем больше степень интеграции рынков и выше мобильность агентов, тем выше реакция и отражение изменений в ценах всех членов интеграционного объединения. О сближении уровней 
цен внутри СБМ говорит невысокий коэффициент вариации индекса потребительских цен на продовольствие, который составил всего 14\% [3].

\section{Выводы}

Итак, в странах СБМ наблюдается положительная динамика развития аграрного сектора, отмеченная ростом урожайности и производства. Благодаря более рациональному использованию трудовых ресурсов они достигли некоторого роста производительности труда (в 2-3 раза по сравнению с уровнем производительности труда в традиционном хозяйстве). Одновременно возникли заметные структурные изменения в воспроизводственном процессе; в частности, начинал повышаться товарный выход зерна. Ещё одним фактором, обусловившим рост товарности агросферы стран СБМ, стала диверсификация производства, продиктованная интеграционными процессами и наличием спроса на соседних рынках. Таким образом, происходит поступательный отход от монокультурного хозяйства и освоение дополнительных товарных культур, обозначились признаки начала перехода хозяйств на стадиально более высокий этап технико-экономической эволюции - капиталоёмкий с ограниченным трудосберегающим эффектом. И хотя эти процессы проходят достаточно неоднородно по странам СБМ, различными темпами, всё же наблюдается тенденция сближения уровней сельскохозяйственного производства по субрегиону.

Это подтверждает ожидаемый эффект интеграции, при котором, согласно экономической теории, в интеграционном объединении наблюдается догоняющее развитие и выравнивание общего уровня развития.

\section{Список литературы}

1. Agricultutal Trade Facilitation in the Greater Mekong Subregion / Asian Development Bank. - Manila, 2012. - 24 p.

2. CDRI. Agriculture Trade in the Greater Mekong Subregion. - Phnom Penh, 2009. 22 p.

3. FAOSTAT Data. - URL: http:/www.fao.org/faostat/en/\#data/QC (дата обращения: 09.03.2020).

4. Greater Mekong Subregion Statistical Database. - URL: https://www.gr eatermekong.org/statistics/index-static.php (дата обращения: 09.03.2020).

5. Ministry of Commerce of Cambodia. Trade Statistics. - URL: http://www.mo c.gov.kh/en-us/Trade-Info/Trade-Statistics (дата обращения: 19.02.2020).

6. Ministry of Commerce. Foreign Trade Statistics of Thailand. - URL: http://tradereport.moc.go.th/TradeEng.aspx (дата обращения: 01.03.2020).

7. Myanmar Statistical Information Service. - URL: http://www.mmsis.gov.m $\mathrm{m} / \mathrm{sub}$ _menu/statistics/statDbList.jsp?vw_cd=MT_ZTITLE (дата обращения: 17.02.2020). 
8. Rice and Poverty in the Greater Mekong Subregion // AEC News Today. 2.03.2016. - URL: https://aecnewstoday.com/2016/rice-poverty-greater-mekong-subregion/ (дата обращения: 20.01.2020).

9. Vietnam Customs. Statistical Data. - URL: https://www.customs.gov.vn/Lis ts/EnglishStatistics/StatisticalData.aspx?language=en-US\&Group=Statistical\%20data (дата обращения: 09.03.2020).

10. World Bank. Corridor Performances Assessment. Phnom Penh, 2014. 44 p.

\section{References}

1. Agricultutal Trade Facilitation in the Greater Mekong Subregion. ADB. Manila, 2012. $24 \mathrm{p}$.

2. Agriculture Trade in the Greater Mekong Subregion. CDRI. Phnom Penh, 2009. $22 \mathrm{p}$.

3. FAOSTAT Data. Available at: http://www.fao.org/faostat/en/\#data/QC (accessed 09 March 2020).

4. Greater Mekong Subregion. Statistical Database. Available at: https://www.greatermekong.org/statistics/index-static.php (accessed 09 March 2020).

5. Ministry of Commerce of Cambodia. Trade Statistics. Available at: http://www.moc.gov.kh/en-us/Trade-Info/Trade-Statistics (accessed 19 February 2020).

6. Ministry of Commerce. Foreign Trade Statistics of Thailand. Available at: http://tradereport.moc.go.th/TradeEng.aspx (accessed 01 March 2020).

7. Myanmar Statistical Information Service. Available at: http://www.mmsis.go v.mm/sub_menu/statistics/statDbList.jsp?vw_cd=MT_ZTITLE (accessed 17 February 2020).

8. Rice and Poverty in the Greater Mekong Subregion. AEC News Today. 2.03.2016. Available at: https://aecnewstoday.com/2016/rice-poverty-greater-mekongsub-region/ (accessed 20 January 2020).

9. Vietnam Customs. Statistical Data. Available at: https://www.customs.gov. vn/Lists/EnglishStatistics/StatisticalData.aspx?language=en-

US\&Group=Statistical\%20data (accessed 09 March 2020).

10. World Bank. Corridor Performances Assessment. Phnom Penh, 2014. 44 p. 